УДК 378. 015. $31-051: \mathrm{III} / 852(043.3)$

DOI:

Маріанна Мирошникова, здобувач кафедри педагогіки

Хмельницької ууманітарно-педагогічної академії

викладач кафедри загальноправових та соџіально-гуманітарних дисциилін

Херсонського факультету Одеського державного університету внутрішніх справ

\title{
КРИТЕРІЇ ТА ПОКАЗНИКИ СФОРМОВАНОСТІ ЕСТЕТИЧНОЇ КУЛЬТУРИ МАЙБУТНІХ ОФІЦЕРІВ НАЦІОНАЛЬНОЇ ПОЛІЦІЇ УКРАЇНИ
}

Стаття присвячена теоретичному обтрунтуванню критеріїв та показників сформованості естетичної культури майбутніх офічерів начіональної поліції. Наголошується, що успішне вирішення завдань естетичної освіти і виховання курсантів вищих навчальних закладів МВС України є можливим лише за умови глибокого усвідомлення особливостей та існуючого стану сформованості естетичноі культури як особистісного духовно-функціонального утворення, яке визначає ставлення до естетичних иінностей, забезпечує повноцінне освоєння та використання на практиці.

Ключові слова: естетична культура, майбутні офічери національної полічії, критерії та показники сформованості естетичної культури.

Табл. 2. Літ. 17.

Marianna Myroshnykova, Applicant of the Pedagogy Department Khmelnytskiy Humanitarian Pedagogical Academy Lecturer of the General Law and Social and Humanitarian Disciplines Department Kherson Faculty of Odessa State University of Internal Affairs

\section{CRITERIAAND INDICATORS OF THE FORMATION OF AESTHETIC CULTURE OF FUTURE OFFICERS OFTHE NATIONAL POLICE OF UKRAINE}

The article is devoted to the theoretical substantiation of the criteria and indicators of the formation of the aesthetic culture of future officers of the national police. It is noted that the successful solution of the tasks of aesthetic education and education of cadets of higher educational establishments of the Ministry of Internal Affairs of Ukraine is possible only under the condition of a deep awareness of the peculiarities and the existing state of formation of aesthetic culture as a personal spiritual and functional entity, which determines the relation to aesthetic values, ensures the full development and use on practice.

The author analyzes the modern approaches to outstanding criteria and indicators of the formation of the aesthetic culture of the individual, highlights the expediency of certain criteria and indicators of the formation of aesthetic culture of student youth in the context of such approaches as epistemological, cultural, axiological, personality-oriented, competence, organizational-activity, synergetic and systemic. According to the results of the research and the empirical experience of diagnosing the author of the article considers that it is expedient to use in practice such criteria and indicators of the formation of the aesthetic culture of future officers of the national police as their attitude (formal, pragmatic, spiritual) to aesthetic values; mastering (reproductive, constructive, creative) aesthetic values; use (spontaneous, conscious, systematic) of aesthetic values in the process of various activities.

Aesthetic culture is considered by the author as a phenomenon that has a complex nature. It has a certain structure, mechanisms of self-organization, embraces the emotional, intellectual and creative forces and capabilities of the individual. The author stresses that it is possible to assess the state of the formation of the aesthetic culture of the major officers of the national police by taking into account the most important aspects, components and parameters of its development and functioning. The article highlights the systemic, dynamic and multi-layered aesthetic culture of future police officers. The materials of the article highlight the diagnostic questions of the formation of the aesthetic culture of future police officers.

The author gives a description of the criteria and indicators that determine the formation of the aesthetic culture of the personality of the police officer. The author emphasizes that the most optimal level of use in practice of aesthetic values is the systematic introduction by the future law enforcers of an aesthetic idea that covers the most important aspects of life and work, makes it aesthetically meaningful and expressive.

Keywords: aesthetic culture, the future officers of the national police, the criteria and indicators of the formation of the aesthetic culture.

7 остановка проблеми. Досліджуючи вчені (В. Андрущенко, В. Луговий, О. Слюсаренко, проблему модернізації вищої освіти Ж. Таланова, О. Голубенко, І. Грищенко, К. Балабанов україни в контексті євроінтеграції та ін.) зазначають, що університетська освіта не 


\section{КРИТЕРІЇ ТА ПОКАЗНИКИ СФОРМОВАНОСТІ ЕСТЕТИЧНОЇ КУЛЬТУРИ МАЙБУТНІХ ОФІЦЕРІВ НАЦІОНАЛЬНОЇ ПОЛІЦІЇ УКРАЇНИ}

тільки не втрачає своєї історично сформованої ролі, а й посилює їі. Зміни торкаються не історичної місії університетів, а конкретного змісту, форм організації та технологій навчання. 3 погляду вчених, головне призначення університетів у всі часи полягало в збагаченні наукового знання, залученні до культури, продукуванні інтелектуальної еліти держави і суспільства, підтриманні наукових академічних традицій. Для збереження за університетами ролі служителів потребам суспільства потрібні такі атрибути, як: підготовка / соціалізація студентів до їхньої ролі в житті суспільства; забезпечення всім студентам шансів на соціальну мобільність; захист університету як домівки для безкорисної наукової дискусії. Першу функцію університету - підготовка молоді до ії ролі у житті суспільства - можна поділити на три типи: підготовка до життя в спільноті, підготовка до інтелектуального життя та підготовка до професійної діяльності. Соціалізація індивідів до життя в спільноті означає передусім підготовку до участі в громадських справах і демократичних процесах, тобто це підготовка до громадської участі в демократичному житті спільноти [1, 11 - 13].

Акцентуючи увагу на положеннях, що характеризують модернізацію вищої школи в Україні, вважаємо доцільним зазначити, що в цьому процесі суттєво посилюється роль естетичної освіти і виховання студентської молоді, надання питанню формування естетичної культури майбутніх фахівців пріоритетного характеру. Адже йдеться про підготовку студентської молоді до встановлення активного діалогу з естетичними цінностями минулого й сьогодення, формування у юнаків та дівчат відповідального ставлення до естетичних цінностей, розгортання широкої програми залучення майбутніх фахівців до збереження, збагачення та активного використання на практиці духовних, культурних і естетичних цінностей.

Для прийняття оптимальних педагогічних рішень 3 цих питань важливим є вивчення сучасного стану сформованості естетичної культури майбутніх фахівців. Про це пише В. Аннєнков, зауважуючи, що для реалізації цільової програми розвитку й виховання студентів вищої школи потрібна наукова аргументація на основі емпіричних (в томучислі експериментальних) досліджень стану реальних інтересів, виборів, переваг, пріоритетів молоді. Серед них заслуговують на увагу результати досліджень особистісних детермінант, зокрема, системи ціннісних орієнтацій поведінки та діяльності студентської молоді $[2,94]$.
Для цілеспрямованого вивчення існуючого стану сформованості естетичної культури майбутніх офіцерів національної поліції важливо мати чітке усвідомлення сутності естетичної культури як складного особистісного духовнофукціонального утворення, а також глибоке розуміння основних параметрів його розвитку, динамічних змін тощо. Для цього потрібні відповідні критерії та показники, спираючись на які можна робити висновки, здійснювати аналіз, порівняння, узагальнення щодо змін, які відбуваються у сфері естетичного розвитку та діяльності майбутніх правоохоронців.

Аналіз сучасних досліджень і публікацій. У науковій літературі питання критеріїв та показників естетичної вихованості студентської молоді знайшли певне висвітлення. Йдеться про обгрунтування критеріїв та показників сформованості естетичного смаку у студентів (Т. Бабенко), системи естетичних цінностей у майбутніх учителів (О. Софіщенко), естетичної культури у студентів вищих навчальних закладів (М. Бабков), естетичної вихованості слухачів вищої школи системи МВС України засобами мистецтва (М. Баранов), естетичного смаку студентів і курсантів вищих навчальних закладів МВС України засобами іноземних мов (В. Вертегел), естетичних компетенцій у курсантів вищих навчальних закладів МВС України засобами іноземної мови (Т. Зубач), морально-естетичної вихованості курсантів вищих навчальних закладів МВС України (Н. Карпунова, Т. Ісаєнко, А. Картін), естетичних ідеалів студентської молоді(О. Кайданова).

Заслуговують на увагу дослідження, присвячені визначенню критеріїв та рівнів сформованості естетичної культури майбутніх офіцерів-прикордонників (О. Косінова), естетичної культури особистості з ознаками лідерської обдарованості (К. Лесик), естетичного ставлення учнівської иолоді до мистецтва (В. Бутенко), естетичного відношення до людини у курсантів вищих начальних закладів системи МВС України (Н. Могілевська), художньо-естетичної вихованості студентської молоді (Ю. Пастухова), естетичної свідомості та ставлення саршокласників до світу прекрасного (Т. Шевченко, Л. Печко), естетичної культури юриста (А. Романова), естетичної культури студентів педагогічних університетів у позааудиторній художній діяльності (І. Сідорова), естетичної вихованості студентської молоді засобами масової інформації (С. Сургай). Естетичної культури майбутніх дизайнерів (В. Томашевський) та ін.

Водночас, питання критеріїв та показників сформованості естетичної культури майбутніх 


\section{КРИТЕРІЇ ТА ПОКАЗНИКИ СФОРМОВАНОСТІ ЕСТЕТИЧНОӤ КУЛЬТУРИ МАЙБУТНІХ ОФІЦЕРІВ НАЦІОНАЛЬНОЇ ПОЛІЦІЇ УКРАЇНИ}

офіцерів національної поліції ще не було предметом наукового пошуку, не знайшло необхідного висвітлення у науковій літературі. Це не сприяє ефективній організації діагностики стану сформованості естетичної культури як системного духовно-функціонального утворення особистості, не дозволяє кваліфіковано оцінювати естетичний розвиток курсантів вищих навчальних закладів МВС України.

Мета статті полягає у висвітленні наукових підходів до оцінки сформованості естетичної культури особистості, а також обгрунтуванні критеріїв та показників, необхідних для визначення сформованості естетичної культури майбутніх офіцерів національної поліції.

Виклад основного матеріалу. Важливо зазначити, що естетична культура являє собою явище, яке має складну природу, детермінується у своєму розвитку та функціонуванні як зовнішніми, так і внутрішніми чинниками впливу, характеризується тим, що має певну структуру, механізми самоорганізації, охоплює емоційні, інтелектуальні та креативні сили і можливості особистості. Це переконує в тому, що оцінити стан сформованості естетичної культури особистості виявляється можливим лише за умови урахування найважливіших аспектів, складових та параметрів розвитку й функціонування цього системного, динамічного й багаторівневого утворення особистості, яке визначає ії ставлення до естетичних цінностей, їх плідне освоєння та використання на практиці.

Усвідомлення особливостей естетичної культури особистості спонукає вчених до використання окремих підходів до оиінки сформованості естетичної культури, надання відповідної характеристики тим можливостям, які пов'язані з певною системою та інтерпретацією дій. За таких обставин у науковій літературі знайшли своє висвітлення наукові підходи до оцінки, аналізу та інтерпретації сформованості естетичної культури особистості. До таких підходів віднесено: гносеологічний, аксіологічний, культурологічний, особистісно-орієнтований, організаційно-діяльнісний, синергетичний та ін. (табл. 1).

Можемо бачити, що наукові підходи до визначення сформованості естетичної культури особистості дозволяють виокремити низку важливих критеріїв та показників [3 - 17]. Так, О. Косінова пропонує такі критерії, як емоційний, інтелектуальний та діяльнісний. В. Лень поділяє критерії на три групи: критерії цілей, засобів та шляхів досягнення мети. Т. Широкоград пропонує низку критеріїв та показників естетичної вихованості особистості. Л. Грицай обгрунтовує доцільність таких критеріїв, як рецептивний, когнітивний, емотивний, аксіологічний, системно-діяльнісний. М. Киященко, Н. Лейзеров, Н. Крилова акцентують увагу на таких критеріях сформованості естетичної культури особистості, як розвиток естетичного ставлення, естетичних поглядів та естетичних потреб. Г. Петрова вважає доцільними такі критерії, як емоційно-оцінний, пізнавальний та діяльнісний. Л. Печко переконує у необхідності урахування у процесі діагностики сформованості морально-естетичної культури особистості світоглядного компонента (почуття, погляди, орієнтації, спрямованість, мотиви, установки та самооцінки); операційнодіяльнісного компонента (естетичні установки); системно-результативного компонента (якість естетико-етичної освіченості; система уподобань у сфері естетики, мистецтва, моралі; естетичне світовідчуття, мислення та діяльність; спрямованість на передачу естетико-морального досвіду у професійній діяльності, створення умов естетизації професійних процесів та ін.).

Безперечно, наукові розвідки вчених мають важливе значення для процесу діагностики сформованості естетичної культури особистості, дозволяють ураховувати окремі прояви цього духовного утворення. Водночас залишається без належного осмислення питання, що пов'язане 3 вивченням стану сформованості естетичної культури майбутніх офіцерів національної поліції. У науковій літературі ще не знайшли висвітлення критерії та показники, які слід враховувати під час визначення готовності правоохоронців до активної взаємодії та зв'язку з проявами естетичного у повсякденному житті та професійній діяльності.

На основі теоретичного обгрунтування цього питання нами запропоновані відповідні критерії та показники сформованості естетичної культури майбутніх офіцерів національної поліції. До них віднесено такі критерії, як ставлення до естетичних цінностей, освоєння естетичних цінностей та використання на практиці естетичних цінностей (табл. 2).

Ставлення майбутніх офіцеерів поліції до естетичних иінностей. Цей критерій сформованості естетичної культури має важливе значення. Адже у процесі діагностики виникає необхідність з'ясування того, наскільки спрямованими на взаємодію 3 проявами прекрасного в дійсності та професійній діяльності $\epsilon$ правоохоронці. Як засвідчують результати наукових спостережень, майбутні офіцери поліції по-різному ставляться до проявів естетичного. Це 


\section{КРИТЕРІЇ ТА ПОКАЗНИКИ СФОРМОВАНОСТІ ЕСТЕТИЧНОЇ КУЛЬТУРИ МАЙБУТНІХ ОФЦЦЕРІВ НАЦІОНАЛЬНОЇ ПОЛІЦІЇ УКРАЇНИ}

\begin{tabular}{|c|c|c|c|}
\hline \multicolumn{4}{|c|}{ Наукові підходи до визначення сформованості естетичної культури особистості } \\
\hline № & Назва наукових підходів & $\begin{array}{c}\text { Інтерпретація сутності } \\
\text { естетичної культури особистості }\end{array}$ & $\begin{array}{c}\text { Основні параметри } \\
\text { сформованості естетичної } \\
\text { культури особистості }\end{array}$ \\
\hline 1. & Гносеологічний підхід & $\begin{array}{l}\text { Естетична культура особистості } \\
\text { інтерпретується як сукупність } \\
\text { способів освоєння естетичного в } \\
\text { дійсності та мистецтві }\end{array}$ & $\begin{array}{l}\text { 1)Емоційні способи освоєння } \\
\text { естетичного; 2) } \\
\text { інтелектуальні способи } \\
\text { естетичного; } 3 \text { ) діяльнісні } \\
\text { способи освоєння } \\
\text { естетичного. }\end{array}$ \\
\hline 2. & Аксіологічний підхід & $\begin{array}{l}\text { Естетична культура особистості } \\
\text { інтерпретується як ціннісне } \\
\text { ставлення до дійсності та } \\
\text { мистецтва }\end{array}$ & $\begin{array}{l}\text { 1) Прагматичне ставлення до } \\
\text { дійсності та мистецтва; } \\
\text { 2) художнє ставлення до } \\
\text { дійсності та мистецтва; } \\
\text { 3) духовне ставлення до } \\
\text { дійсності та мистецтва. }\end{array}$ \\
\hline 3. & Культурологічний підхід & $\begin{array}{l}\text { Естетична культура особистості } \\
\text { інтерпретуєтья як умова } \\
\text { розвитку художньо-творчої } \\
\text { діяльності }\end{array}$ & $\begin{array}{l}\text { 1) Вплив естетичної культури } \\
\text { на розвиток музичного } \\
\text { мистецтва; } \\
\text { 2) вплив естетичної культури } \\
\text { на розвиток образотворчого } \\
\text { мистецтва; 3) вплив } \\
\text { естетичної культури на } \\
\text { розвиток художньої } \\
\text { літератури. }\end{array}$ \\
\hline 4. & $\begin{array}{l}\text { Особистісно- } \\
\text { орієнтований підхід }\end{array}$ & $\begin{array}{l}\text { Естетична культура особистості } \\
\text { інтерпретується як складова } \\
\text { розвитку особистості }\end{array}$ & $\begin{array}{l}\text { Розвиток естетичної } \\
\text { культури: } \\
\text { 1) у дітей дошкільного віку; } \\
\text { 2) в учнів загальноосвітньої } \\
\text { школи; } \\
\text { 3) у студентської молоді. }\end{array}$ \\
\hline 5. & $\begin{array}{l}\text { Організаційно-діяльнісний } \\
\text { підхід }\end{array}$ & $\begin{array}{l}\text { Естетична культура особистості } \\
\text { інтерпретується як умова } \\
\text { організації діяльності за } \\
\text { законами краси }\end{array}$ & $\begin{array}{l}\text { Організація діяльності: } \\
\text { 1) естетико-ігрової; } \\
\text { 2) естетико-пізнавальної; } \\
\text { 3) художньо-естетичної. }\end{array}$ \\
\hline 6. & Синергетичний підхід & $\begin{array}{l}\text { Естетична культура особистості } \\
\text { інтерпретується як } \\
\text { самоорганізуюча система }\end{array}$ & $\begin{array}{l}\text { 1) Естетичне самовідчуття } \\
\text { особистості; 2) естетична } \\
\text { самооцінка особистості; } \\
\text { 3) естетична самоорганізація } \\
\text { особистості. }\end{array}$ \\
\hline
\end{tabular}

певним чином впливає на подальший процес освоєння і використання на практиці естетичних цінностей.

Спираючись на означений критерій діагностична практика отримує можливість оцінити стан сформованості естетичної культури майбутніх офіцерів поліції i, зокрема, зосередити увагу на характерних проявах ставлення правоохоронців до естетичних цінностей. Йдеться про формальне ставлення до естетичних цінностей, яке засвідчує встановлення зв'язку зі світом прекрасного 3 урахуванням лише формальних ознак, зовнішніх, атрибутивних аспектів того, що пов'язане 3 проявами естетичного в дійсності та правоохоронній діяльності. Прагматичне ставлення до естетичних цінностей засвідчує про вияв інтересу правоохоронців до естетичних цінностей 3 урахуванням їх функціонального прояву, спроможності посилити ефективність та якість професійних дій. Духовне ставлення до естетичних цінностей $є$ найбільш оптимальним для встановлення плідного зв'язку зі світом прекрасного. Адже, спираючись на духовні інтереси, орієнтації, потреби та світоглядні позиції майбутні офіцери поліції спроможні встановлювати духовно-ціннісний зв'язок 3 естетичними проявами дійсності і вибудовувати подальшу свою діяльність 3 урахуванням не лише формальних аспектів та прагматичних цілей, але 


\section{КРИТЕРІЇ ТА ПОКАЗНИКИ СФОРМОВАНОСТІ ЕСТЕТИЧНОЇ КУЛЬТУРИ}

МАЙБУТНІХ ОФЩЦЕРІВ НАЦІОНАЛЬНОӤ ПОЛІЦІЇ УКРАЇНИ

Таблиця 2.

Критерії та показники сформованості естетичної культури майбутніх офіцерів національної поліції

\begin{tabular}{|c|c|c|c|c|}
\hline \multirow[t]{2}{*}{ №№ } & \multirow{2}{*}{$\begin{array}{c}\text { Критерії сформованості } \\
\text { естетичної культури } \\
\text { майбутніх офіцерів поліції }\end{array}$} & \multicolumn{3}{|c|}{ Показники сформованості естетичної культури } \\
\hline & & Низький рівень & Середній рівень & Високий рівень \\
\hline 1. & $\begin{array}{c}\text { Ставлення майбутніх офіцерів } \\
\text { поліції до естетичних } \\
\text { цінностей }\end{array}$ & $\begin{array}{l}\text { Формальне } \\
\text { ставлення до } \\
\text { естетичних } \\
\text { цінностей }\end{array}$ & $\begin{array}{l}\text { Прагматичне } \\
\text { ставлення до } \\
\text { естетичних } \\
\text { цінностей }\end{array}$ & $\begin{array}{c}\text { Духовне } \\
\text { ставлення до } \\
\text { естетичних } \\
\text { цінностей }\end{array}$ \\
\hline 2. & $\begin{array}{c}\text { Освоєння майбутніми } \\
\text { офіцерами поліції естетичних } \\
\text { цінностей }\end{array}$ & $\begin{array}{l}\text { Репродуктивне } \\
\text { освоєння } \\
\text { естетичних } \\
\text { цінностей }\end{array}$ & $\begin{array}{l}\text { Конструктивне } \\
\text { освоєння } \\
\text { естетичних } \\
\text { цінностей }\end{array}$ & $\begin{array}{l}\text { Креативне } \\
\text { освоєння } \\
\text { естетичних } \\
\text { цінностей }\end{array}$ \\
\hline 3. & $\begin{array}{c}\text { Використання на практиці } \\
\text { майбутніми офіцерами поліції } \\
\text { естетичних цінностей }\end{array}$ & $\begin{array}{c}\text { Спонтанне } \\
\text { використання } \\
\text { естетичних } \\
\text { цінностей }\end{array}$ & $\begin{array}{c}\text { Свідоме } \\
\text { використання } \\
\text { естетичних } \\
\text { цінностей }\end{array}$ & $\begin{array}{c}\text { Системне } \\
\text { використання } \\
\text { естетичних } \\
\text { цінностей }\end{array}$ \\
\hline
\end{tabular}

й 3 метою надання цьому процесу повноцінного естетичного змісту.

Освоєння майбутніми офіцерами поліції естетичних иінностей. Цей критерій сформованості естетичної культури відіграє важливу роль у процесі діагностики сформованості естетичної культури. Адже йдеться про те, що естетична культура $є$ тим утворенням особистості, яке знаходиться у стані свого розвитку, збагачення, посилення функціональних можливостей щодо самоорганізації тощо. Звідси виникає необхідність створення таких умов, за якими естетична культура буде набувати нових можливостей, сприяти у здійсненні ефективного сприймання, пізнання, оцінки та інтерпретації естетичних цінностей. Майбутні офіцери поліції покликані бути готовими до таких дій, спиратися на власні можливості забезпечувати тим самим плідне освоєння естетичного в навколишній дійсності та професійній діяльності.

Можемо бачити, що освоєння майбутніми правоохоронцями естетичних цінностей може бути різним. Так, визначаючи репродуктивний характер освоєння естетичних цінностей діагностична практика тим самим засвідчує, що майбутні правоохоронці мають обмежені можливості щодо самостійного сприймання, оцінювання та інтерпретації естетичних проявів дійсності і зосереджують свої зусилля переважно на репродуктивних способах отримання естетичного досвіду. Водночас конструктивне освоєння естетичних цінностей має більш широкі можливості пізнання прекрасного в силутого, що спирається не лише на емоційні, але й на інтелектуальні зусилля правоохоронців. Креативне освоєння естетичних цінностей відкриває майбутнім офіцерам поліції широку панораму дій, серед яких провідну роль відіграє креативно-естетична активність, пов'язана 3 такими способами освоєння естетичних цінностей, як їх сприймання, оцінка та творча інтерпретація.

Використання на практиці майбутніми офіцерами поліції естетичних иінностей. Цей критерій сформованості естетичної культури дозволяє оцінити готовність правоохоронців до впровадження власного естетичного досвіду в умовах повсякденного буття, спілкування, навчання, відпочинку, професійної діяльності. Необхідність урахування у діагностичному процесі означеного критерія зумовлене тим, що естетична культура особистості не $\epsilon$ самоціллю. Вона формується для того, щоб приносити користь людині, створювати необхідні умови для естетизації іiі життєдіяльності, збагачення змісту та форм самореалізації з урахуванням не лише проявів корисного, доцільного, але й того, що робить життя виразним, красивим, захоплюючим.

Безперечно, використання майбутніми офіцерами поліції естетичних цінностей може бути різним. Визначити якості характеристики цього процесу можуть допомогти такі показники, як спонтанне, свідоме та системне використання естетичних цінностей. У процесі діагностики сформованості естетичної культури майбутніх офіцерів поліції спонтанне використання естетичних цінностей може засвідчувати, що правоохоронці не готові до самостійного вирішення цих питань і знаходяться, переважно, під впливом зовнішніх чинників. Конструктивне освоєння естетичних цінностей засвідчує про більш якісні дії, пов’язані з вибудовою логічно 


\section{КРИТЕРІЇ ТА ПОКАЗНИКИ СФОРМОВАНОСТІ ЕСТЕТИЧНОЇ КУЛЬТУРИ МАЙБУТНІХ ОФІЦЕРІВ НАЦІОНАЛЬНОЇ ПОЛІЦІЇ УКРАЇНИ}

оформлених рішень, з посиленням ролі естетичних аспектів професійної діяльності. Найбільш оптимальним рівнем використання на практиці естетичних цінностей $є$ системне упровадження майбутніми правоохоронцями естетичної ідеї, яка охоплює найважливіші аспекти життєвої та професійної діяльності, робить її естетично змістовною і виразною.

Висновки і перспективи подальших досліджень. Теоретичне вивчення зазначеної проблеми дозволило проаналізувати сучасні наукові підходи до визначення сформованості естетичної культури особистості і водночас обгрунтувати основні критерії та показники, які доцільно використовувати у процесі діагностики стану сформованості естетичної культури майбутніх офіцерів національної поліції. Подальший науковий пошук передбачає отримання відповіді на питання, що пов'язані 3 проведенням констатувального експерименту та аналізом даних, що характеризують рівні сформованості естетичної культури майбутніх правоохоронців.

\section{ЛІТЕРАТУРА}

1. Андрущенко В.П. Майбутнє університетів XXI століття спроба прогностичного аналізу / В.П. Андрущенко // Педагогічна і психологічна науки в Україні: зб. наук. праць в 5т. Київ: "Педагогічна думка", 2012. Т.5: Вища освіта. С. $11-30$.

2. Аннєнков В.П., Хахуда С.М. Розвиток системи ціннісних орієнтацій студентів в умовах ВНЗ I - II рівнів акредитації / В.П. Анненков // Теоретикометодологічні проблеми розвитку особистості в системі неперервної освіти: матеріли методологічного семінару АПН України 16 грудня 2004 р. /за ред. С.Д. Максименко. - Київ, 2005. С. 94 -99 .

3. Бабенко Т.В. Формування естетичного смаку у студентів вищих педагогічних навчальних закладів засобами іноземних: автореф. дис.... канд. пед. наук.: 13.00.04. Житомир, 2006. - 20 с.

4. Бабков М. І. Формування естетичної культури у студентів юридичних вищих навчальних закладів: автореф. дис. на здобуття наук. ступеня кандидата пед. наук. Луганськ, 2010. - 20 с.

5. Енциклопедія освіти / голов. ред. В. Г. Кремень. Київ, 2008. - 1040 с.

6. Зубач Т.О. Формування естетичних компетенцій у курсантів вищих навчальних закладів МВС України засобами іноземної мови // Педагогічні науки: зб. наук. праць. Херсон, 2010. Вип.55. С. $274-277$.

7. Киященко Н.И., Лейзеров Н.Л. Теория отражения и проблемы эстетики. Москва, 1983. С.92-145.

8. Косінова О.М. Визначення критеріїв та рівнів оцінки сформованості естетичної культури майбутніх офіцерів-прикордонників // Матеріли XIII Міжнар. наук. інтернет-конференції “Соціум. Наука. Культура”
(25-27 січня 2017p.) URL: http://intkonf.org/kosinovaom-viznachennya-kriteriyiv-pokaznikiv-ta-rivniv-otsinkisformovanosti-estetichnoyi-kulturi-maybutnih-ofitserivprikordonnikiv/

9. Котелюх М.О. Модель формування професійної моралі мабутніх працівників поліції // Педагогіка формування творчої особистості у вищій і загальноосвітній школах. 2015. Вип. 44. С. 181-190.

10. Крылова Н. Б. Культурология образования // Новые ценности образования. Москва, 2000. Вып. 10. C. $76-77$.

11. Лень В.С. Співвідношення критеріїв та показників оцінки ефективності новацій // Вісник Черніг. держ. технол. ун-ту. 2000. №11. С.38-45.

12. Мамчур Н.С. Теоретико-методологічні засади поняття “естетична культура особистості" // Гуманітарний вісник ДВНЗ “Переяслав-Хмельницький держ. пед. ун-ту ім. Григорія Сковороди”. 2016. Вип. 7. Том 5 (60). С. 136-144.

13. Мельничук С. Г. Теорія і практика формування естетичної культури майбутніх учителів (історикопедагогічний аспект). Кіровоград, 2006. 248c.

14. Отич О. Особливості художньо-естетичного розвитку особистості у системі професійної освіти. URL: http://lib.iitta.gov.ua/5884/1/\%D1\%81\%D1 $\% 82 \% \mathrm{D} 0 \%$ B0\%D1\%82\%D1\%82\% D1\%8F_\%D0\% 9E\%D1\%82\%D0\%B8\%D1\%87.pdf

15. Петрова Г.А. Воспитание эстетической культуры // Разработка модели системы воспитания в высшем учебном заведении (на опыте Казанского государственного университета URL: https:// www.google.com.ua/url?sa $=$ t\&rct $=\mathrm{j} \& \mathrm{q}=\&$ esrc $=\mathrm{s} \& \mathrm{~s}$ o u r c e $=$ w e b \& c d $=1 \& \mathrm{c}$ a d $=\mathrm{r} \mathrm{j}$ a\&uact $=8 \& v e d=0$ ahUKEwjiofOU2ObYAhXF_KQK HZEJB08QFggnMAA\& url=http $\% 3 \mathrm{~A} \% 2 \mathrm{~F} \% 2 \mathrm{~F}$ old.kpfu.ru\%2Finfres $\% 2$ Fni kolaev $\% 2$ F $2001 \% 2 \mathrm{Fgl}$ 2_1_2.htm\&usg=AOvVaw0GkCXuTajOYd1SuOcqOAIb

16. Романова А.С. Естетична культура юриста як поліструктурне явище // Митна справа. - 2011. - №5. C. $448-456$.

17. Серебряк В.В. Духовно-моральне виховання курсантів вищих навчальних закладів системи МВС України: автореф. дис. на здобуття наук. ступеня кандидата пед. наук. Луганськ, 2004. - 20 с.

\section{REFERENCES}

1. Andrushchenko, V.P. (2012). Maibutnie universytetiv XXI stolittia sproba prohnostychnoho analizu [The Future of the Universities of the XXI Century an attempt of a prognostic analysis] Pedagogical and psychological science in Ukraine: Sb. sciences works in 5t. Kyiv: Pedagogical Thought, pp. 11 - 30. [in Ukrainian].

2. Annienkov, V.P. \& Khakhuda, S.M. (2005). Rozvytok systemy tsinnisnykh oriientatsii studentiv $\mathrm{v}$ umovakh VNZ I - II rivniv akredytatsii [Development of System of Value Orientations of Students in the Conditions of Higher Educational Institutions of I - II Levels of Accreditation]. Teoretyko-metodolohichni problemy rozvytku osobystosti $v$ systemi neperervnoi osvity: materily metodolohichnoho seminaru APN Ukrainy 16 


\section{КРИТЕРІЇ ТА ПОКАЗНИКИ СФОРМОВАНОСТІ ЕСТЕТИЧНОӤ КУЛЬТУРИ МАЙБУТНІХ ОФІЦЕРІВ НАЦІОНАЛЬНОЇ ПОЛІЦЇ УКРАЇНИ}

hrudnia 2004 r. - Theoretical and methodological problems of personality development in the system of continuous education: materials of the methodological seminar of the Academy of Pedagogical Sciences of Ukraine December 16, 2004 / ed. S.D Maksimenko, (pp.94-99). Kyiv. [in Ukrainian].

3. Babenko, T.V. (2006). Formuvannia estetychnoho smaku u studentiv vyshchykh pedahohichnykh navchalnykh zakladiv zasobamy inozemnykh mov [Formation of Aesthetic Taste of Students of Higher Pedagogical Educational Institutions by Means of Foreign Languages]. Extended abstract of candidate's thesis. Zhytomyr. 20 p. [in Ukrainian].

4. Babkov M. I. (2010). Formuvannia estetychnoi kultury u studentiv yurydychnykh vyshchykh navchalnykh zakladiv [Formation of Aesthetic Culture among Law Students of Higher Educational Institutions]. Extended abstract of candidate's thesis. Lugansk, 20 p. [in Ukrainian].

5. Kremen, V.G. (Ed.). (2008). Entsyklopediia osvity [Encyclopedia of Education]. Kyiv, 1040 p. [in Ukrainian].

6. Zubach, T.O. (2010). Formuvannia estetychnykh kompetentsii u kursantiv vyshchykh navchalnykh zakladiv MVS Ukrainy zasobamy inozemnoi movy [Formation of Aesthetic Competences in Cadets of Higher Educational Institutions of the Ministry of Internal Affairs of Ukraine by Means of Foreign Language]. Ped science, vol. 55, pp. $274-277$. [in Ukrainian].

7. Kyiashchenko, N.Y. \& Leizerov, N.L. (1983). Teoryia otrazhenyia y problemi estetyky [Theory of reflection and the problems of aesthetics]. Moscow, pp. 92-145. [in Russian].

8. Kosinova, O.M. (2017). Vyznachennia kryteriiv ta rivniv otsinky sformovanosti estetychnoi kultury maibutnikh ofitseriv-prykordonnykiv [Determination of Criteria and Levels of Assessment of the Formation of Aesthetic Culture of Future Border Guards Officers]. Materily XIII Mizhnar. nauk. internet-konferentsii "Sotsium. Nauka. Kultura" (25-27 sichnia 2017r.) Proceedings of the 13th International Sciences Internet Conference "Socium. Science. Culture" (January 25-27, 2017) URL: http://intkonf.org/kosinova-omviznachennya-kriteriyiv-pokaznikiv-ta-rivniv-otsinkisformovanosti-estetichnoyi-kulturi-maybutnih-ofitserivprikordonnikiv/ [in Ukrainian].

9. Koteliukh, M. O. (2015). Model formuvannia profesiinoi morali mabutnikh pratsivnykiv politsii [A model of formation the professional morale of future police officers]. Pedagogy of formation of a creative person in higher and secondary schools, vol.44, pp. 181190. [in Ukrainian].

10. Krilova, N. B. (2000). Kulturolohyia obrazovanyia
[Culturology of Education]. Moscov, vol.10, pp. 76-77. [in Russian].

11. Len, V.S. (2000). Spivvidnoshennia kryteriiv ta pokaznykiv otsinky efektyvnosti novatsii [Value of Criteria and Indicators for Assessing the Effectiveness of Innovations]. A bulletin of Chernihiv State Technology University, no.11, pp.38-45. [in Ukrainian].

12. Mamchur, N.S. (2016). Teoretyko-metodolohichni zasady poniattia "estetychna kultura osobystosti" [Theoretical and methodological principles of the concept of "aesthetic culture of personality"]. A Humanitarian Bulletin of the State Higher Educational Establishment "Pereyaslav-Khmelnytskiy Hryhoriy Skovoroda State Pedagogical University". Issue 7, vol. 5 (60), pp. 136-144. [in Ukrainian].

13. Melnychuk, S. H. (2006). Teoriia i praktyka formuvannia estetychnoi kultury maibutnikh uchyteliv (istoryko-pedahohichnyi aspekt). [Theory and Practice of Forming the Aesthetic Culture of Future Teachers (Historical and Pedagogical Aspect).Kirovohrad, 248 p. [in Ukrainian].

14. Otych, O. Osoblyvosti khudozhno-estetychnoho rozvytku osobystosti u systemi profesiinoi osvity. [Features of artistic and aesthetic personality development in the system of vocational education]. URL:http://lib.iitta.gov.ua/5884/1/\%D1\%81\%D1\%8 $2 \% \mathrm{D} 0 \% \mathrm{~B} 0 \% \mathrm{D} 1 \% 82 \% \quad \mathrm{D} 1 \% 82 \quad \% \mathrm{D} 1 \% 8 \mathrm{~F}$ $\%$ D0\%9E\%D1\%8 2\%D0\% B8\%D1 \%87.pdf[in Ukrainian].

15. Petrova, H.A. Vospytanye estetycheskoi kulturi/ /Razrabotka modely systemi vospytanyia $v$ visshem uchebnom zavedenyy (na opite Kazanskoho hosudarstvennoho unyversyteta [Education of aesthetic culture. Development of a model of the system of upbringing in a higher educational institution (based on the experience of the Kazan State University]. URL: h t t p s : / / w w w. g o o g l e.com . u a /

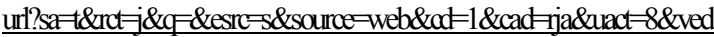
=0hUKEwiilOU2ObYAhXF KQKHZEJBO8QFgnMAA\&un Hitp $\% / 3 \mathrm{~A} \%$ 2F\%2Fold.kpfu.ru\%2Finfres $\% 2$ Fnikolaev $\% 2 \mathrm{~F}$ $2001 \% 2 \mathrm{Fg} 212 \mathrm{htm} \& u$ se $=$ AOvVaw0GkCXuTajOYd1SuOcqOAlb [in Ukrainian].

16. Romanova, A.S. (2011). Estetychna kultura yurysta yak polistrukturne yavyshche [The aesthetic culture of a lawyer as polystructural phenomenon]. Mytna sprava, no.5, pp.448 -456. [in Ukrainian].

17. Serebriak, V.V. (2004). Dukhovno-moralne vykhovannia kursantiv vyshchykh navchalnykh zakladiv systemy MVS Ukrainy [Spiritual and Moral Education of Cadets of Higher Educational Institutions of the Ministry of Internal Affairs of Ukraine]. Extended abstract of candidate's thesis. Luhansk, 20 p. [in Ukrainian].

Стаття надійшла до редакції 20.02.2018

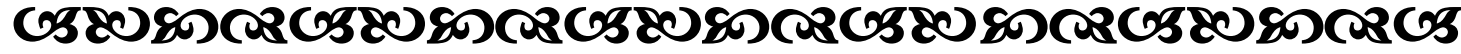

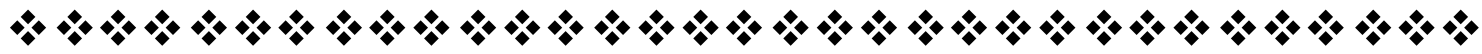

